\title{
Local perspectives on water
}

\author{
By J. G. Hering, ${ }^{1,2,3,{ }^{*}}$ D. L. Sedlak, ${ }^{4}$ C. Tortajada, ${ }^{5,6}$ A. K. Biswas, ${ }^{5,6}$ C. Niwagaba, ${ }^{7}$ T. Breu ${ }^{8}$ \\ ${ }^{1}$ Eawag, Swiss Federal Institute of Aquatic Science and Technology, Dübendorf, Switzerland. ${ }^{2}$ Institute of \\ Biogeochemistry and Pollutant Dynamics (IBP), Swiss Federal Institute of Technology (ETH), Zürich, \\ Switzerland. ${ }^{3}$ School of Architecture, Civil and Environmental Engineering (ENAC), Swiss Federal Institute \\ of Technology (EPFL), Lausanne, Switzerland. ${ }^{4}$ University of California, Berkeley, ReNUWIt Engineering \\ Research Center, Berkeley, USA. ${ }^{5}$ Cofounder, Third World Centre for Water Management, Atizapán, Mexico. \\ ${ }^{6}$ Lee Kuan Yew School of Public Policy, National University of Singapore, Singapore. ${ }^{7}$ Department of Civil \\ and Environmental Engineering, College of Engineering, Design, Art, and Technology (CEDAT), Makerere \\ University, Kampala, Uganda. ${ }^{8}$ Centre for Development and Environment (CDE), University of Bern, Bern, \\ Switzerland.*E-mail: janet.hering@eawag.ch
}

A global perspective on water management predominates in high-level policy discussions. This has the advantage that over-arching issues can be highlighted and international resources mobilized. But water issues arise from local conditions and can only be resolved by people and institutions with local authority and responsibility. High-level policies can only have meaningful impact if they are informed by and responsive to local and regional contexts. In keeping with the principle of subsidiarity, highlevel policy-making should support local and regional interests, efforts, and policies.

LOCATION IS IMPORTANT. Renewable freshwater resources derive from precipitation over land, which exhibits substantial spatial and temporal variability. Natural conveyance and storage are also spatially differentiated. The geography of major rivers, deltas, and coastlines has strongly influenced patterns of human settlements, trade, fishing, and agriculture. This is reflected in localized patterns of water demand and alteration of water systems, including draining of wetlands, river channelization, and construction of dams and canals. Urban areas have been local sources of pollution to waterways and coastal areas (1).
How infrastructure investment decisions are made can have profound impacts on local livelihoods and development. A global perspective is likely to distract attention and resources away from opportunities to adopt proven effective measures and build on past reforms whose success was based on principle and pragmatism (2). Installation of drinking water treatment plants in North America in the early 20th century is estimated to have extended life spans by up to 7 years (3). Investments in urban drainage reduced losses from flooding, draining of wetlands removed habitat for disease vectors, and construction of sewers and municipal wastewater treatment improved public health and supported recovery of aquatic habitat and fisheries. Dam construction provided water for irrigation, municipal and industrial supply, and electricity generation, as well as flood protection. These gains and associated economic development were accompanied by costs and environmental impacts (1), some of which are no longer considered acceptable. This has led to investment in restoration and alternative approaches to water management.

Developing countries face substantial infrastructure deficits. An estimated 2.5 billion people, mainly in low- and middle-income

This is the accepted manuscript of the following article:

Hering, J. G., Sedlak, D. L., Tortajada, C., Biswas, A. K., Niwagaba, C., \& Breu, T. (2015). Local perspectives on water. Science, 349(6247), 479-480. http://doi.org/10.1126/science.aac5902 
countries, still lack access to improved sanitation; uncontrolled release of human waste and inadequate sewage treatment pose severe health risks (4). Water quality in rapidly industrializing countries is degraded by discharge of inadequately treated domestic and industrial effluents (1). Waste management that is appropriate for local conditions is needed to recover water, energy, and nutrients.

dOES A GLOBAl PERSPECTIVE help? Global policy-making, specifically adoption of the Millennium Development Goals (MDGs), has directed attention to lack of access to safe drinking water and sanitation. Yet the sanitation goal remains unmet (4), and pressing issues that go beyond access (e.g., fecal sludge management) have not been adequately addressed (5). The drinking water goal is compromised because access to improved water sources does not guarantee adequate water quality (4). The post-MDG Sustainable Development Goals will require integrated approaches for water management tailored to local conditions, as well as water-quality standards that can be monitored and related to health outcomes.

Institutions with a global reach (6) have an important role to play in sharing information on effective agricultural practices. Irrigated agriculture contributes to increased food security but also can negatively affect biodiversity and groundwater reserves. Increasing water productivity of crop yield in rain-fed areas will require improved water- and land-management practices that are adapted to local conditions and practices. Crop rotation, mulching, and minimizing tillage could increase water-use efficiency. Floodwater harvesting and rainwater runoff trapping are underexploited opportunities for increasing water storage in soil (7). Management of soil water, evaporation, and noncrop evapotranspiration is needed.
Agricultural demand for water is linked globally through trade in agricultural commodities, which results in a modest increase in the efficiency of water use (8). Virtual water transfer is an observable phenomenon, but it does not constitute a viable policy instrument. It fails to account for local damage resulting from poor water management practices in agriculture. For example, export-oriented agricultural production may increase the competition for water at the expense of local land-use systems, especially in arid and semiarid areas. Agricultural production in areas with high water productivity can be constrained by other factors, including energy demand, labor costs, or highervalue uses of land.

Calls for a global perspective on water governance have accompanied shifts in power from local authorities to a broader coalition of officials, bureaucrats, and interest groups. It is at the local level that interactions, tradeoffs, and choices matter most. Local actors are well positioned to deal with management issues subject to specific needs and constraints and reflecting relevant perceptions, aspirations, interests, and agendas (2, 9). Local-level capacity development for water management may improve governance more generally.

International water management is needed where rivers or lakes cross or define national boundaries. There are often no agreements on how to structure development to the benefit of the countries involved. Past agreements focusing mainly on water allocation were negotiated on a "zero-sum" basis. Many institutions for transboundary water management have limited enforcement authority and effectiveness. Static agreements and institutions are not responsive to changing conditions. A more positive direction in transboundary water management incorporates potential benefits to multiple development sectors (10). This can only be effective if 
assessment of potential benefits reflects local conditions, constraints, and opportunities.

Water resources should be assessed and managed at the scale that is most effective. Concepts promoted from a global perspective may be insufficiently transferable to local contexts and/or may fail to reflect changing circumstances. A focus on the river-basin scale may be counterproductive if the size and complexity of the system overwhelm capacity for joint decision-making and management by the riparian states. A nested, tiered framework for analysis (11) may help identify the most effective scale for water management; a single scale may not be most effective in all cases or for all aspects of a single case.

\section{REFERENCES AND NOTES}

1. United Nations Environment Programme, Environment for the future we want (UNEP, Malta, 2012), www.unep.org/geo/geo5.asp.

2. J. Briscoe, paper presented at the OECD Global Forum on Environment: Making Water Reform Happen, Paris, 25 to 26 October 2011; www.oecd.org/env/resources/48925318.pdf.
3. D. Sedlak, Water 4.0: The Past, Present, and Future of the World's Most Vital Resource (Yale Univ. Press New Haven, CT, 2014). Google Scholar

4. United Nations, The Millennium Development Goals report 2014 (UN, New York, 2014); www.un.org/millenniumgoals/reports.shtml.

5. L. Strande, M. Ronteltap, D. Brdjanovic, Eds., Faecal Sludge Management: Systems Approach for Implementation and Operation (IWA publishing, London, 2014). Google Scholar

6. Institutions such as the International Water Management Institute (www.iwmi.cgiar.org/) and the UN Convention to Combat Desertification (www.unced.int/en/Pages/default.aspx) serve as clearinghouses for information.

7. R. Mekdaschi-Studer, H. Liniger, Water harvesting: Guidelines to good practice (Centre for Development and Environment, University of Bern, Bern, 2013); http://bit.ly/WaterHarvest-pdf.

8. M. M. Mekonnen, A. Y. Hoekstra, Hydrol. Earth Syst. Sci. 15, 1577-1600 (2011).

9. A. K. Biswas, C. Tortajada, Int. J. Water Resour. Dev. 26, 129-139 (2010).

10. O. Varis, C. Tortajada, A. K. Biswas, Eds., Management of Transboundary Rivers and Lakes (Springer, Berlin, 2008).

11. E. Ostrom, Proc. Natl. Acad. Sci. U.S.A. 104, 15181-15187 (2007). 